\title{
PARTICIPATORY DECISION - MAKING AND ITS IMPLEMENTATION IN NIGERIA: AN EXPERIENCE FROM PHARMACEUTICAL INDUSTRIES LTD., AWE
}

\author{
Emmanuel Olaniyi Dunmade*)1 \\ *) Department of Industrial Relations \& Personnel Management, Faculty of Management Sciences, University of Ilorin \\ P.M.B, 1515, Ilorin, Nigeria
}

\begin{abstract}
In as much as employees' participation in the workplace's decision making has been found to have favourable effects on both the employees and the employers, participative management should therefore be considered an inevitable tool in any organization - be it public or private. The study examined participatory decision making and its implementation in Nigeria with a focus on Pharmaceutical Industries Ltd., Awe, Oyo - State. The sample size of the study was 177 with the adoption of a structured questionnaire as the data collection's instrument, while the random sampling technique was utilized. The adoption of the method was based on its easy usage and capacity to correctly represent an enormous population. The descriptive statistics employed comprised frequency, percentage and tables, while regression was used as inferential statistics. The finding of the study showed a significant relationship between employees' direct involvement in the Bond Chemical industries' decision making and the implementation. The finding also established significant facilitation of the organization's decision making by the employees' consultation. The study concludes that there is a significant effect of employees' participation on the implementation of Bond Chemical Industries, while employees' adequate sensitization on participatory decision making coupled with an attachment of reward system to the practice was recommended for workers' full commitment.
\end{abstract}

Keywords: employees' involvement, employees' voice, co-partnership, joint consultation, participatory decision - making

\begin{abstract}
Abstrak: Sebanyak partisipasi karyawan dalam pengambilan keputusan tempat kerja telah ditemukan memiliki efek yang menguntungkan baik bagi karyawan dan pengusaha, oleh karena itu manajemen partisipatif harus dianggap sebagai alat yang tak terhindarkan dalam organisasi mana pun - baik itu publik atau wasta. Studi ini meneliti pengambilan keputusan partisipatif dan implementasinya di Nigeria dengan fokus pada Pharmaceutical Industries Ltd., Awe, Oyo - State. Besar sampel penelitian adalah 177 dengan adopsi kuesioner terstruktur sebagai instrumen pengumpulan data, sedangkan teknik pengambilan sampel digunakan secara acak. Pengadopsian metode ini didasarkan pada kemudahan penggunaan dan kapasitasnya untuk mewakili populasi yang sangat besar dengan tepat. Statistik deskriptif yang digunakan terdiri dari frekuensi, persentase dan tabel, sedangkan regresi digunakan sebagai statistik inferensial. Hasil penelitian menunjukkan adanya hubungan yang signifikan antara keterlibatan langsung karyawan dalam pengambilan keputusan industri Bond Chemical dan implementasinya. Temuan tersebut juga menetapkan fasilitasi signifikan dalam pengambilan keputusan organisasi melalui konsultasi karyawan. Studi ini menyimpulkan bahwa terdapat pengaruh yang signifikan dari partisipasi karyawan terhadap penerapan Bond Chemical Industries, sedangkan kepekaan karyawan yang memadai terhadap pengambilan keputusan partisipatif ditambah dengan lampiran sistem penghargaan pada praktik direkomendasikan untuk komitmen penuh pekerja.
\end{abstract}

Kata kunci: keterlibatan karyawan, suara karyawan, kemitraan bersama, bersama konsultasi, pengambilan keputusan partisipatif

${ }^{1}$ Corresponding author:

Email: dunmade.eo@unilorin.edu.ng 


\section{INTRODUCTION}

Employees' participation in management is a critical ingredient of industrial democracy as the concept is turning out to be progressively important in almost every organization since participative decision making is one of the important aspects of organizational life with which increased organizational effectiveness and employees' commitment towards organizational goals could be easily achieved (Anteneh, 2018). This is due to the fact that there is no modern and forward- looking workplace that would want its workforces to be kept in dark when it comes to critical decisions affecting them. The organization would continually count on and include its workers in the business decisions that would move it forward given that the 'Command and Control model' is no longer adopted by any establishment in the contemporary time in that more open and concerted efforts do work wonders in exploiting the employees' talents (Uma, 2015).

The practice of organizational management over the years, particularly in the early days of the assembly line and scientific management required employees to completely perform all duties assigned to them by their employers. Even though, this was absolutely a classical method of obtaining results through others; it is therefore no more in vogue in nowadays' business world as the trend has improved given that organization's expectations from its employees have increased than for the workers to just do exactly what is being dictated to them. This has equally changed given that employees too desire further than merely working in accordance with the directions of their superiors (Ezennaya, 2011). This is in addition to the advent of participative management theory and an increase in the realization that employees often possess something valuable and worthwhile. Therefore, as stressed by Rachmawati, Maarif and Sukmawat (2020), good human management is required for the organization to improve its performance.

On the other hand, according to Ezennaya (2011), workers in the workplace ordinarily do prefer and cherish being inquired of how they are feeling on their assigned tasks and how the introduction of their personal ideas can make the allocated works to be done not only in a better way, but also faster and easier. However, the rationale behind this change in emphasis is not far from the management's discovery of the existence of meaningful business value associated with seeking and utilizing ideas of individuals at every organizational level since the workplace's success is largely dependent on the extent at which employees are allowed to participate in the key organizational decisions required for outsmarting the competitors (Dede, 2019). The reason for the change in emphasis is also occasioned by the present day intense business competitions and the turbulent work environment mandating workplaces not only to seek means for more job flexibility and adaptability, but also to strive for competitive advantage as they are confronted with cutthroat pressures and frequently changing markets (David, 2005).

Participative decision-making refers to the shared decision-making or the degree to which employers allow or encourage their workforces to partake in organizational decision-making (Talib \& Rahman, 2010). This is a key component in advancing employees' work satisfaction, while as well indicating the management's fair treatment of its employees to accomplish the organizational goals since this plays a critical role in effectively implementing the workplace's strategies (Harber et al. 1991; Ardichvili et al. 2003). Employees' participation does not denote a goal or a tool as some organizations practice it, rather it has to do with the creation of an environment in which workforces have an impact on actions and decisions that affect their work. This is a management and leadership philosophy on how employees are utmost permitted to contribute to the continuous advancement and success of their organization. This in turn, improves the employees' commitment towards the implementation of the workplace's already reached decisions as this is an emotional and mental replication that results in the fulfillment of personal and organizational goals, mainly if upheld by the organization's climate, knowing fully well that this goes a long way to help in building trust between employees and their supervisors, while also ensuring intrinsic rewards (Cross, 2019).

According to Harpreet (2019), nowadays in Nigeria, there have been lots of controversies regarding whether or not employees, particularly at the low level of management should participate in managerial decisionmaking. While certain management writers opined that participative decision-making is non-existence in the country, and where it does it is not genuine, being that the required conditions to support participation are not provided. Though it has been advocated for from some quarters that each worker in the organization should 
contribute to decision making in the organization, particularly where he/she is affected. Harpreet (2019) maintains that such participation is expected not to only serve as training, but also as a testing ground for the future members of the upper management.

Over the years, the lack of or inadequate employees' participation in the decision-making process of many establishments in Nigeria has led to the workers' job dissatisfaction which had equally resulted to employees' agitations, confrontations; and unrest, while these have adversely affected the level of employees' support for the successful implementation of the organizations' decisions and economic policies. While the widespread strike actions within organizations have contributed to low or declined productivity in the country since decision-making in the workplaces has been the purview of top management with the partial or total exclusion of workers on the lower management ranks who are ordinarily the individuals always saddled with the responsibility of implementing these decisions (Oyaro, 2016). However, it is considered necessary for the management of organizations in Nigeria to realize employees' participation in decision-making as a very critical matter to their survival. This is because well-involved workers in the workplace's decisionmaking usually feel being part of the organization, thus strengthens them toward the achievement of the organizational goals.

Although employees' participation in the workplace's decision making appears drawing attention lately in the current business environments, and specifically in Nigeria, but the known previous researches (Isichei and Godwin (2015); Oyebamiji (2018); Dede (2019); Cross (2019); and Kelechi et al. (2019)) in the country were dissimilar in the areas of used variables such as Organizational productivity, employees' performance, and so on for the measurement of the effect of employees' participation in the organization's decision- making. These past studies also vary in their case studies, and also in the time frame in which they were conducted. Yet, it is doubtful whether any empirical study has earlier been carried out on participatory decision-making and its implementation in Bond Pharmaceutical Industries Limited, Awe Town in Nigeria. It is thus this gap that this study tries to fill. This is with the specific objectives to explore the relationship between employees' direct involvement in the organization's decision-making and the implementation of such decisions in Bond Pharmaceutical Industries Limited, Awe; and To investigate the extent to which employees' consultation facilitates the implementation of the organization's decision-making in the study area.

\section{METHODS}

The descriptive survey method was utilized as a research technique for this study. The population includes all the staff members of Bond Pharmaceutical Industries Limited; Awe, Nigeria. This sums up to three Hundred and Eighteen (318) as this was based on the obtained figure in the course of the fieldwork. Thus, using Guilford and Flruchter's formula for sample size determination, the sample size of the study stood at One Hundred and Seventy-Seven (177).

A structured questionnaire was employed for the collection of primary data. The questionnaire was administered at once to participants, whilst the responses were instantly retrieved except where the participants demanded more time. The questionnaire has two sections. The first sub-division focuses on demographic information and educational background of the respondents, while the second sub-division concentrates on drawing information over the: (i) exploration of the relationship between employees' direct involvement in the organization's decision making and the implementation of such decisions in Bond Pharmaceutical Industries Limited, Awe; and (ii) investigation of the extent to which employees' consultation facilitates the implementation of the organization' decision making in the study area. The response rate indicates that out of One Hundred and Seventy-Seven (177) sets of questionnaires administered, One Hundred and Fifty-Six (156) copies were returned, being $88 \%$ response rate (Table 1 ).

Table 1. Response rate

\begin{tabular}{lcc}
\hline Response Rate & Frequency & Percentages (\%) \\
\hline Returned & 156 & $88 \%$ \\
Unreturned & 21 & $12 \%$ \\
$\quad$ Total & 177 & $100 \%$ \\
\hline
\end{tabular}

The administered questionnaire was adapted from the reviewed literature, while it was thereafter validated by an expert in human resource management and who is dexterous in questionnaire design. The questionnaire was drawn up in a close-ended form, as it was designed in a manner that it could be understood by the participants without difficulty. The study adopted Five 
Point Likert Scale as its measurement technique with 1 $=$ strongly disagree, $2=$ disagree, $3=$ Neutral, $4=$ agree, and $5=$ strongly agree. The Cronbach's alpha, which denotes a measure of the reliability of an instrument of the entire subscales is great with the coefficients that are between 0.74 and 0.79 . The study then made use of the random sampling technique with the intention to ensure that every participant in the study area has a chance of being selected. Descriptive techniques such as frequency, percentage and tables were used for characterizing the responses, while regression was adopted as the inferential statistics for the study.

\section{RESULTS}

This segment of the study concentrates on the study's data analysis and the results presentation. Table 2 portrays the case summary of the frequency of the respondent's gender with the valid percentages of their responses. It showed that slightly more than half $(50.6 \%)$ of the participants were males, while $49.4 \%$ were females. This implies that the majority of the respondents were males. The high percentage of males in the organization is an indication that the numbers of male participating in the organization's activities are higher than their female counterparts.

Table 2. Socio-demographic characteristics of the participants

\begin{tabular}{|c|c|c|c|}
\hline Variables & Levels & Frequency (f) & Percentage $(\%)$ \\
\hline \multirow{3}{*}{ Gender } & Male & 79 & 50.6 \\
\hline & Female & 77 & 49.4 \\
\hline & Total & 156 & 100.0 \\
\hline \multirow[t]{5}{*}{ Age } & $<25$ years & 54 & 34.6 \\
\hline & 26 - 35 years & 47 & 30.1 \\
\hline & 36 - 45 years & 43 & 27.6 \\
\hline & $\geq 46$ years & 12 & 7.7 \\
\hline & Total & 156 & 100.0 \\
\hline \multirow{6}{*}{$\begin{array}{l}\text { Educational } \\
\text { Qualification }\end{array}$} & NCE/OND & 54 & 34.8 \\
\hline & First Degree & 55 & 35.3 \\
\hline & Masters & 24 & 15.4 \\
\hline & Ph.D. & 4 & 2.6 \\
\hline & Others & 19 & 11.9 \\
\hline & Total & 156 & 100 \\
\hline \multirow{5}{*}{$\begin{array}{l}\text { Years of } \\
\text { Working } \\
\text { Experience }\end{array}$} & $<2$ years & 22 & 14.1 \\
\hline & $3-5$ years & 48 & 30.8 \\
\hline & $6-10$ years & 27 & 17.3 \\
\hline & $\geq 11$ years & 59 & 37.8 \\
\hline & Total & 156 & 100.0 \\
\hline \multirow[t]{7}{*}{ Departments } & Production & 76 & 48.9 \\
\hline & Operations/IT & 19 & 11.9 \\
\hline & Marketing & 27 & 17.6 \\
\hline & Accounting & 10 & 6.2 \\
\hline & Human Resources & 16 & 10.1 \\
\hline & Others & 8 & 5.3 \\
\hline & Total & 156 & 100 \\
\hline
\end{tabular}


Table 2 also presents the distribution of the respondents by age. It is shown that $34.6 \%$ were under 25 years of age, $30.1 \%$ were of age $25-35$ years, $27.6 \%$ of $36-45$ years, while $7.7 \%$ were of ages 46 years and above. It can therefore be understood from the analysis that the majority of the respondents were youths who were still under 25 years which is very helpful to the organization (Bond Pharmaceutical Industries Limited, Awe) as these workforces are at their active age to put in their best for the company's success or greatness. Furthermore, the distribution of respondents by their educational qualifications illustrates that $34.8 \%$ of the participants were OND/NCE holders, $35.3 \%$ had a first degree, and $15.4 \%$ had MSc, $2.6 \%$ were with a Ph.D., while $11.9 \%$ of these workforces possessed others qualifications. This suggests that most of the respondents are well educated and Graduates who were in the position to give objective answers to the developed questions in the administered questionnaire. This is following their level of literacy.

Besides, the distribution of respondents by their length of services in Bond Pharmaceutical Industries Limited, Awe shows that $14.1 \%$ of the participants had less than 2 years of working experience, while $30.8 \%$ had between 3-5 years, then $17.3 \%$ had between $6-10$ years, whereas almost $38 \%$ of the participants had working experience of 11 years and above. So, the inference of this is that most of the staff members have been in the workplace for a while or quite long, thus make them have much knowledge and clear understanding on how things work or go in the organization due to their level of participation in the workplace activities and decision - making. Lastly, Table 2 illustrates the respondents by their department in the organization as $48.9 \%$ of them were in the production department, then $11.9 \%$ in operation / IT, $17.6 \%$ were also in Marketing department, $6.2 \%$ too were in Accounting unit, 10.1\% were in Human Resources Management, while $5.3 \%$ of them were indicated to be in other departments not specified. This entails that employees' deployment in
Bond Pharmaceutical Industries Limited, Awe cuts across all the units of the establishment.

\section{Test of Hypotheses}

Ho1: There is no significant relationship between employees' direct involvement in the organization's decision making and the implementation of such decision in Bond Pharmaceutical Industries Limited, Awe.

Table 3 showed a significant linear relationship between employees' direct involvement in the organization's decision making and the implementation of the same decision in Bond Pharmaceutical Industries Limited, Awe. It is shown that employees' direct involvement in the organization's decision making variable on decision implementation yields a coefficient of multiple correlations (R) and square (R2) of .483 and .234 respectively. These values are statistically significant at a 0.05 probability level. In other words, employees' direct involvement in the organization's decision making as a variable could explain $23.4 \%$ of the observed variance in the organization's decision's implementation. The stated null hypothesis is rejected. This implies that there is a significant relationship between employees' direct involvement in the organization's decision making and the implementation of such a decision in Bond Pharmaceutical Industries Limited, Awe. This finding corroborates the outcomes of different studies carried out by Abdulai and Shafiwu (2014), and Cross (2019) respectively. The finding of Abdulai and Shafiwu (2014)'s study indicated a significant relationship between employees' participation and productivity as the decision implementation of the studied banks turned out to be easy each time the staff members were allowed to partake in different stages of the banks' decision making. While Cross (2019) observed a significant relationship between employees' involvement in the organizational decision making and performance of the Nigerian banks that he studied.

Table 3. Summary of regression analyses on relationship between employees' direct involvement in the organization's decision making and implementation

\begin{tabular}{lccccc}
\hline Variable & $\mathrm{B}$ & $\mathrm{SEB}$ & $\beta$ & $\mathrm{t}$ & $\mathrm{p}$ \\
\hline (Constant) & .997 & .151 & & 6.616 & .000 \\
Employees' Direct Involvement & .467 & .056 & .483 & 8.281 & .000 \\
$\mathrm{R}$ & & .483 & & & \\
$\mathrm{R} 2$ & & .234 & & & \\
$\mathrm{~F}$ & & $65.574^{*}$ & & & \\
\hline *p $<.05$. Dependent variable: decision implementation & & &
\end{tabular}


Ho2: Employees' consultation does not significantly facilitate the implementation of the organization's decision making in the study area

Table 4 showed a significant relationship of employee consultation in facilitating the implementation of the organization's decision in Bond Pharmaceutical Industries Limited, Awe. It is shown that employees' consultation variable on the decision implementation yields a coefficient of multiple correlations (R) and square (R2) of .656 and .431 respectively. These values are statistically significant at a 0.05 probability level. In other words, employees' consultation as a variable could explain $43.1 \%$ of the observed variance in the organization's decision making implementation. The stated null hypothesis is rejected. This implies that employees' consultation significantly facilitates the implementation of the organization's decision making in the study area. This result is in congruence with the findings of Anteneh (2018)'s study that confirmed the high effect of employees' participation in decision making on the employees' commitment to achieving Hidasie Telecom Share Company's goals. The result also established a strong and positive relationship between the employees' participation in decision making and the workers' commitment to the establishment.

\section{Findings of the Study}

Following the analysis of the study, the response obtained from the respondents through the administered questionnaires indicates that employees' participation contributes up to $23.4 \%$ of the observed variance in the organization's decision's implementation in Bond Pharmaceutical Industries Limited, Awe. This was particularly during staff's meetings and joint consultative committees, though some staff members, especially those in the junior cadre did not have enough understanding of the entire concept as employees' involvement or participation practice was considered by some of them as a tool for employees' attachment to the organization. For example, some of the respondents disclosed specific organization's values such as the ability to enhance performance, capacity to better use their time, experience a drop in the organizational dispute, and also a decrease in labour conflicts due to their participation in the decision making of the workplace.

However, a few numbers of these workers also made it known that their participation in the decisionmaking had no influence at all on their attachment to the organization and so failed to respond or declared otherwise. The findings of the study further indicated that some employees in the organization are not usually consulted during the workplace's decision making with the belief that there would not be an attachment of compensation. Therefore, the study revealed that employees' consultation could only explain $43.1 \%$ of the observed variance in the organization's decision making and implementation. Some staff members had the notion that regardless of their contributions, management would still impose its policies and wishes, while others lacked trust and had misconception over the concept of employees' participation in the organization's decisions.

Table 4. Summary of regression analysis on the influence of employees' consultation in facilitating the implementation of organization's decision making

\begin{tabular}{lccccc}
\hline Variable & $\mathrm{B}$ & $\mathrm{SEB}$ & $\beta$ & $\mathrm{t}$ & $\mathrm{p}$ \\
\hline (Constant) & .739 & .137 & & 5.406 & .000 \\
Employees' Direct Involvement & .746 & .057 & .656 & 13.047 & .000 \\
$\mathrm{R}$ & & .656 & & \\
$\mathrm{R} 2$ & .431 & & \\
$\mathrm{~F}$ & \multicolumn{7}{c}{$170.211^{*}$} \\
${ }^{*} \mathrm{p}<.05$. Dependent Variable: Implementation of the organization's decision-making
\end{tabular}




\section{Managerial implications}

The management of the organization should as well encourage the willing and full participation of all members of staff in its decision-making without any discrimination or preferences. This can be done through the attachment of a reward system to the practice of employees' participation, while the good opinions of the employees should not be ignored, but should be made to count during implementation. This is consequent to the claim by most of the respondents that some key information regarding staffing plans, financial situations, and investment plans were not made public; while they would wish their opinions in policy formulation and implementation on these issues.

\section{CONCLUSIONS AND RECOMMENDATIONS}

\section{Conclusions}

Resulting from the findings of the study, it can be clearly understood that employees' participation in the workplace's decision making is very critical to the survival of every organization and thus requires serious attention to be able to address unwanted or negative attitudes. This is also to ensure a harmonious relationship between employers and their workforces as the involvement of workers in the organization's decision-making guarantees the workers' full support for the effective and prompt implementation of the organizational decisions. It can therefore be concluded from thisstudy thatemployees'participation is in practice in the Bond Chemical Industries, Ltd., Awe, and that there is a positive and significant relationship between participatory decision making and implementation of the organization's decisions.

\section{Recommendations}

Following the findings of the study, the study thereby recommends that the management of Bond Chemical Industries Ltd., should make it a point of duty to once a while organizing a forum for sensitization of its workforce on the participatory decision or theimportance of employees' involvement in the organization decision making not only to the organization but also to the workers. This is required as the finding showed that some staff members, mainly the junior cadre workers did not have enough understanding of the employees' involvement or participation practice.

\section{REFERENCES}

Abdulai IA, Shafiwu AB. 2014. Participatory decision making and employee's productivity. A case study of community banks in the upper east region of Ghana. Business and Economics Journal 5(3): 1 - 10 .

Anteneh AD. 2018. Role of participative decisionmaking in improving employees' commitment towards organizational goal the case of selected district of Hidasie Telecom Share Company [thesis]. Ethiopia: Department of Public Administration and Development Management, Addis Ababa University, Ethiopia.

Cross OD. 2019 Impact of employee participation on decision making in Nigerian banking sector. IOSR Journal of Business and Management 21(2):14-20.

David F. 2005. Strategies Management: Concept and Cases (10th Ed.). New Jersey: Pearson Prentice Hall.

Dede CH. 2019. Employee participation in decision making and organizational productivity: case study of cross river state board of internal revenue, Calabar. IIARD International Journal of Economics and Business Management 5(1): $84-94$.

Ezennaya NP. 2011. Employee participation in decision making and its impact on productivity: an appraisal of government printing press and two otherprivate publishing firms inEnugu. [Research Project]. Enugu: Department of Management, Faculty of Business Administration, University of Nigeria, Enugu Campus.

Harber D, Marriott F, Idrus N. 1991. Employee participation in TQC: An integrative review. International Journal of Quality \& Reliability Management 8(5). http://dx.doi. org/10.1108/02656719110144346.

Harpreet S. 2019. Impact of employee participation in decision making on organizational productivity. [dissertation] Selinus: Business Administration submitted to Selinus University of Sciences and Literature, School of Business and Media.

Isichei EE, Godwin UD. 2015. Employees' participation in decision making and the hospitality industry in Nigeria: An investigative study of selected hotels in the Federal Capital Territory, Abuja, Nigeria. Academic Journal of Economic Studies 1(4): 54-66.

Kelechi EU, Lazarus IO, Ebere O C. 2019. Participative 
decision making and employee's performance in the hospitality industry: A study of selected hotels in Owerri metropolis, Imo State. Management Studies and Economic Systems (MSES) 4(1): 57-70.

Nonaka I. 2005. A dynamic theory of knowledge creation: organizational science. Organization Science 5(1): 14-37. https://doi.org/10.1287/ orsc.5.1.14 .

Oyaro MM. 2016. Influence of employee's involvement in decision making on organizational citizenship behavior: A case of Machakos ounty government. [MBA's research project]. Kenya: Chandaria School of Business, United States International University Nairobi, Kenya.

Oyebamiji FF. 2018. Influence of employees' participation in decision making on organization performance: A study of Ladoke Akintola
University of Technology Teaching Hospital, Ogbomoso, Oyo State, Nigeria. International Journal of Innovative Social Sciences \& Humanities Research 6(3):8-17.

Rachmawati AN, Maarif MS, Sukmawati A. 2020. Prioritization of human capital development strategy of improving the bank's performance. Indonesian Journal of Business and Entrepreneurship 6(3): 228 - 238. https://doi. org/10.17358/ijbe.6.3.228.

Talib F, Rahman Z. 2010. Critical success factors of TQM in service organizations: a proposed model. Services Marketing Quarterly 31(3): 363-380. https://doi.org/10.1080/15332969.2010.486700.

Uma MH. 2015. Employees' Participation: A tool of motivation and high productivity. Pacific Business Review International 8(3): 99 - 102. 